Web Site: https://jutq.utq.edu.iq/index.php/main

Email: journal@jutq.utq.edu.iq

\title{
Spectrophotometric determination of progesterone and dopamine in breast cancer serum
}

https://doi.org/10.32792/utq/utj/vol12/1/1

\author{
Safaa Sabri Najim \\ Chemistry Department, College of Science, \\ Misan University, Misan- Iraq \\ Tel: +9647712446594, \\ Email: safchem2000@yahoo.com
}

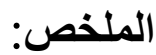

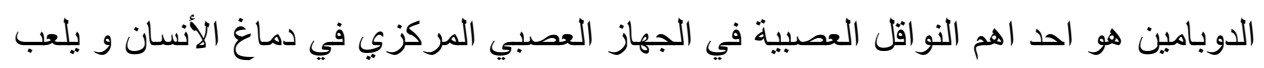

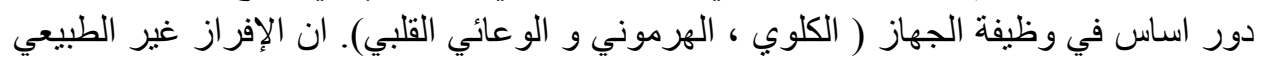

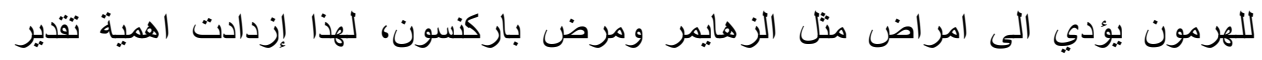

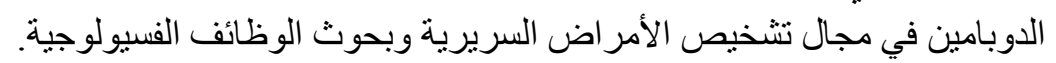

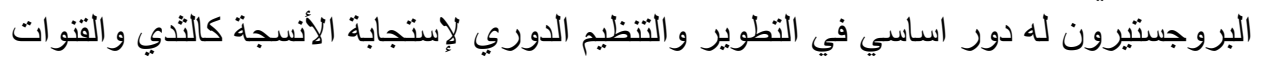

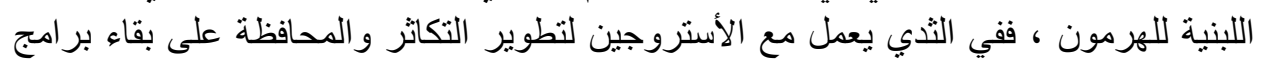

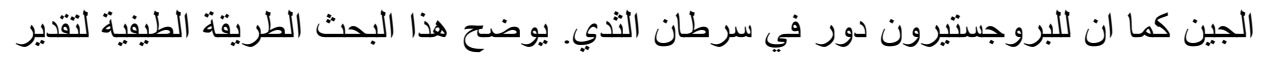

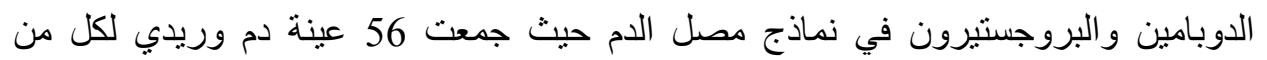

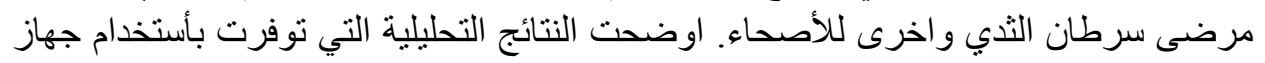

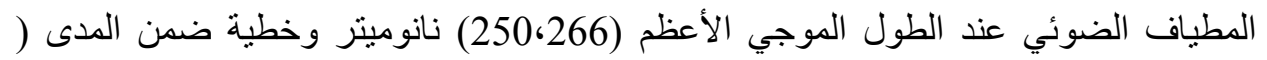

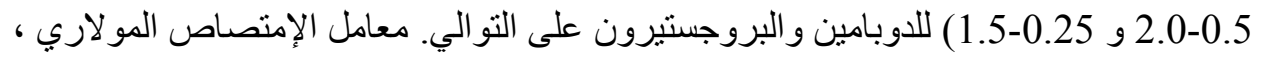
معامل الإرتباط وحد الكثف

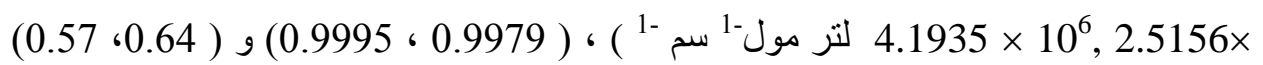
$\left.10^{6}\right)$

للاوبامين والبروجستيرون على التو الي.اوضحت النتائج وجود اختلافات معنوية بين تركيز

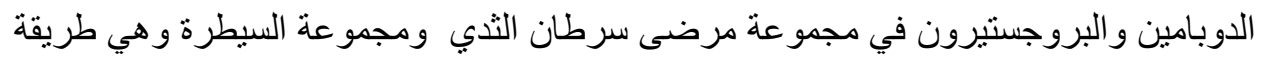
طيفية سريعة وحساسة ويمكن الوثوق بها واليرون واستخدامها عند التقدير الكمي لنماذج بيولونية معقدة. 


\title{
University of Thi-Qar Journal Vol.12 No.1 Mar 2017 \\ Web Site: https://jutq.utq.edu.iq/index.php/main \\ Email: journal@jutq.utq.edu.iq
}

\begin{abstract}
Dopamine (DA) is one of the most important catecholamine neurotransmitters in the human central nervous system in the brain and plays a key role in the functioning of the renal, hormonal, and cardiovascular systems. Abnormal release of DA will contribute to some diseases such as Alzheimer's and Parkinson's disease. Therefore, the sensitive determination of DA becomes increasingly significant in the field of clinical disease diagnosis and the research of physiological functions.
\end{abstract}

Progesterone is an essential for the development and cyclical regulation of hormone responsive tissues including the breast and reproductive tract. In the breast, progesterone acts in concert with estrogen to promote proliferative and pro-survival gene programs. Progesterone has actions in breast cancer.

This paper shows a spectrophotometric method for determination dopamine and progesterone concentration in serum samples, fifty six veins blood samples collected from healthy control and breast cancer patient groups. The analytical data obtained by using UVSpectrophotometer $\left(\lambda_{\max }=250,266 \mathrm{~nm}\right)$, linearity $(0.5-2.0,0.25-1.5$ $\mathrm{ng} / \mathrm{ml}$ ) for dopamine, progesterone respectively. The molar absorptivity ( $\varepsilon$ ), correlation coefficient $\left(\mathrm{R}^{2}\right)$ and limit of detection (LOD) for dopamine, progesterone $\left(\varepsilon=2.5156 \times 10^{6}, 4.1935 \times 10^{6} \mathrm{~L} \cdot \mathrm{mol}^{-1} \mathrm{~cm}^{-1}\right)$, $\left(\mathrm{R}^{2}=0.9979,0.99957\right)$ and $(0.64,0.57 \mathrm{ng} / \mathrm{ml})$ respectively. The results show significant differences between the concentrations of dopamine and progesterone in control and breast cancer patient groups $(\mathrm{p}<0.05)$.It is fast, sensitive, selective and reliable quantification spectrophotometric method used in complex biological samples.

Keywords: dopamine, progesterone, spectrophotometric, breast cancer.

\section{Introduction}

Dopamine (DA), 2-(3,4-dihydroxyphenyl) ethylamine, is a kind of neurotransmitter which plays an important role in the function of 


\section{University of Thi-Qar Journal Vol.12 No.1 Mar 2017 \\ Web Site: https://jutq.utq.edu.iq/index.php/main \\ Email: journal@jutq.utq.edu.iq}

mammalian central nervous, renal, hormonal and cardiovascular systems .It is one of the most crucial catecholamines and belongs to the family of excitatory chemical neurotransmitters. It is derived from tyrosine and is the precursor to norepinephrine and epinephrine.

The hydrochloride salt of DA.HCl as shown in Figure-1 can be supplied as a medication in the treatment of shock, which may be caused by trauma, heart attack, open heart failure, kidney failure and severe bacterial infections of the blood. Excess amounts of DA in the brain often cause pleasurable, rewarding feelings, and sometimes even euphoria, while the deficiency of DA in the brain could cause a few central nervous system disorders, such as Alzheimer's and Parkinson's disease [15].

The most frequent spectral methods for dopamine determination such as, ultraviolet-visible absorption [6-17], fluorescence [18-24], and chemiluminescence [25]. Electroanalytical methods, namely, voltammetry [26-29], amperometry [30], and polarography [31, 32], were also described in the literature.

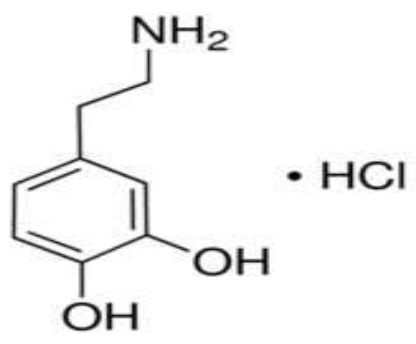

Figure-1 Dopamine hydrochloride structure

Recently, great efforts were done in this direction with a lot of long, expensive, and sophisticated procedures using, for example, monolayer of triazole on gold electrodes [33], using gold nanoparticles [34-36], using modified glassy carbon electrode [37, 38] and using silver nanoparticles [39]. Fast and simple isocratic HPLC method for the determination of DA, 3,4-dihydroxyphenylacetic acid (DOPAC), 


\section{University of Thi-Qar Journal Vol.12 No.1 Mar 2017 \\ Web Site: https://jutq.utq.edu.iq/index.php/main \\ Email: journal@jutq.utq.edu.iq}

norepinephrine (NE), and serotonin (5-HT) in homogenate samples of mouse striatum employing the direct fluorescence of the neurotransmitters [40].

Effective derivatization method followed by high-performance liquid chromatography (HPLC) coupled to electrochemical ionization mass spectrometry to measure the levels of serotonin (5-hydroxyltryptamine, 5HT), DA, 3,4-hydroxyphenylacetic acid (DOPAC), 3- methoxytyramine (3-MT) and homovanillic acid (HVA) simultaneously [41].

Steroids belong to a group of substances with a structural core formed by cyclopenta perhydrophenanthrene and they play an important role in human physiology. Some steroids, such as progesterone as shown in Figure-2, act like sex hormones, responsible for sexual characteristics and supports for reproduction [42-44]. Steroids analyses in different matrices have been possible through analytical separation techniques such as liquid chromatography (HPLC) [45, 46], capillary zone electrophoresis (CZE) [47], micellar electrokinetic chromatography (MEKC) [48], and capillary electrochromatography (CEC) [49, 50].

A separation technique in liquid medium that has gained significant interest in recent years is the CEC, which combines some characteristics of both HPLC and capillary electrophoresis (CE) [51].

Progesterone is a steroid hormone that is produced primarily by the corpus luteum in the ovaries during the second half of the menstrual cycle or luteal phase. Progesterone is also produced, to a lesser extent, in the adrenal glands and, during pregnancy, the placenta. Thus, cyclical hormone exposure beginning at menarche and ending in menopause occurs monthly and regulates the growth and differentiation of specialized tissues within the reproductive tract and breast tissues[52] pregnancy interrupts this process and is characterized by high progesterone levels, which are required for fetal development, breast development for lactation, maintenance of uterine/placental integrity, and myometrial quiescence [53]. In the present study, serum levels of dopamine and progesterone hormones were measured spectrophotometric method in breast cancer patient and control groups. 
University of Thi-Qar Journal Vol.12 No.1 Mar 2017

Web Site: https://jutq.utq.edu.iq/index.php/main

Email: journal@jutq.utq.edu.iq

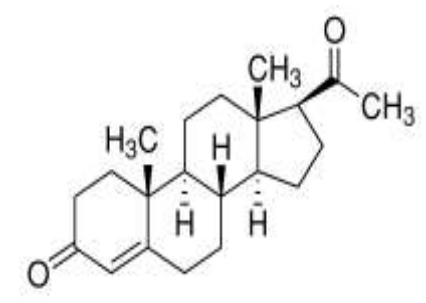

Figure-2 Progesterone structure 


\section{University of Thi-Qar Journal Vol.12 No.1 Mar 2017 \\ Web Site: https://jutq.utq.edu.iq/index.php/main \\ Email: journal@jutq.utq.edu.iq}

\section{Materials and methods}

\subsection{Instrumentation}

All absorbance readings were measured using UV-2800 Labomed Spectrophotometer connected to hp Laser jet-1300 printer with quartz cell.

\subsection{Preparation of solutions}

\subsubsection{Stock solution of dopamine hydrochloride (DA.HCl)}

A weight of $0.0125 \mathrm{~g}$ of dopamine $\mathrm{HCl}$ (sigma-aldrich) dissolved in ethanol, transferred into volumetric flask $(50 \mathrm{ml})$, diluted with ethanol to the mark and mixed $(0.250 \mathrm{mg} / \mathrm{ml})$.

\subsubsection{Stock solution of progesterone}

A weight of $0.0125 \mathrm{~g}$ of progesterone (sigma-aldrich) dissolved in chloroform, transferred into volumetric flask $(50 \mathrm{ml})$, diluted with chloroform to the mark and mixed $(0.250 \mathrm{mg} / \mathrm{ml})$.

\subsubsection{Standard solution of dopamine hydrochloride}

Transferred $4 \mu \mathrm{L}$ by the micropipette from the stock solution $(0.250$ $\mathrm{mg} / \mathrm{ml})$ to volumetric flask $(10 \mathrm{ml})$, diluted with ethanol to the mark, working solution $(100 \mathrm{ng} / \mathrm{ml})$ has been prepared. The following volumes $(0.05,0.1,0.15$ and $0.2 \mathrm{ml})$ transferred from the working solution (100 $\mathrm{ng} / \mathrm{ml})$ to four volumetric flasks $(10 \mathrm{ml})$ respectively, diluted with ethanol to the mark, standard solutions $(0.5,1.0,1.5$ and $2.0 \mathrm{ng} / \mathrm{ml})$ were prepared.

\subsubsection{Standard solution of progesterone}

Transferred $4 \mu \mathrm{L}$ by the micropipette from the stock solution $(0.250$ $\mathrm{mg} / \mathrm{ml})$ to volumetric flask $(10 \mathrm{ml})$, diluted with chloroform to the mark, working solution $(100 \mathrm{ng} / \mathrm{ml})$ has been prepared. The following volumes (25, 50, 100 and 150) $\mu \mathrm{L}$ transferred from the working solution (100 


\section{University of Thi-Qar Journal Vol.12 No.1 Mar 2017 \\ Web Site: https://jutq.utq.edu.iq/index.php/main \\ Email: journal@jutq.utq.edu.iq}

$\mathrm{ng} / \mathrm{ml})$ to four volumetric flasks $(10 \mathrm{ml})$ respectively, diluted with chloroform to the mark, standard solutions $(0.25,0.5,1.0$ and $1.5 \mathrm{ng} / \mathrm{ml})$ were prepared.

\subsection{Preparation of samples}

Twenty eight female patients, with histopathological diagnosis of breast cancer, aged 26-62 years were selected from Al-sader public hospital in Misan- Iraq. Twenty eight matched healthy women who attended routine health examination in the same hospital were selected from the same area with no history of any tumor or breast disease. Ten $\mathrm{ml}$ of venous blood without using anticoagulant samples were collected from patients and healthy volunteers in plain screw cap specimen bottles and then left for 30 min for retraction after, which centrifugation was carried out at $3000 \mathrm{rpm}$ for $5 \mathrm{~min}$ and the supernatant serum was aspirated by using pasteur pipette into another plain bottle. The collected supernatant was then pooled and stored at $-20^{\circ} \mathrm{C}$ until the time of analysis. Serum samples was diluted with deionized water and homogenized before analysis.10 $\mu \mathrm{L}$ collected from each single serum sample of the patients and healthy by micropipette, $90 \mu \mathrm{L}$ of deionized water added to each one for analysis.

\section{Results and discussion}

\subsection{Dopamine spectrum}

A $50 \mathrm{ml}$ dopamine solution $(10.5 \mathrm{ng} / \mathrm{ml})$ prepared by serial dilution of the working solution, quartz cell $(1 \mathrm{~cm})$ used for $\lambda_{\max }$ determination (200 - $400 \mathrm{~nm}$ ), ethanol used as a blank, as shown in Figure-3. 
Web Site: https://jutq.utq.edu.iq/index.php/main

Email: journal@jutq.utq.edu.iq

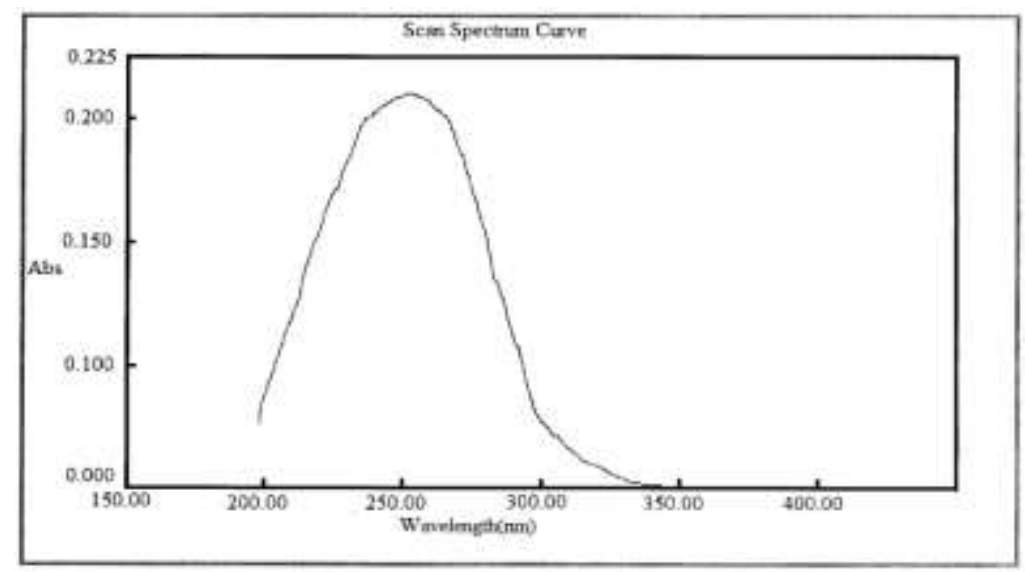

Figure-3, Dopamine absorption spectrum (ng/ml)

\subsection{Progesterone spectrum}

A $50 \mathrm{ml}$ progesterone solution $(3.5 \mathrm{ng} / \mathrm{ml})$ prepared by serial dilution of the working solution, quartz cell $(1 \mathrm{~cm})$ used for $\lambda_{\max }$ determination (200 $400 \mathrm{~nm}$ ), chloroform used as a blank, as shown in Figure-4.

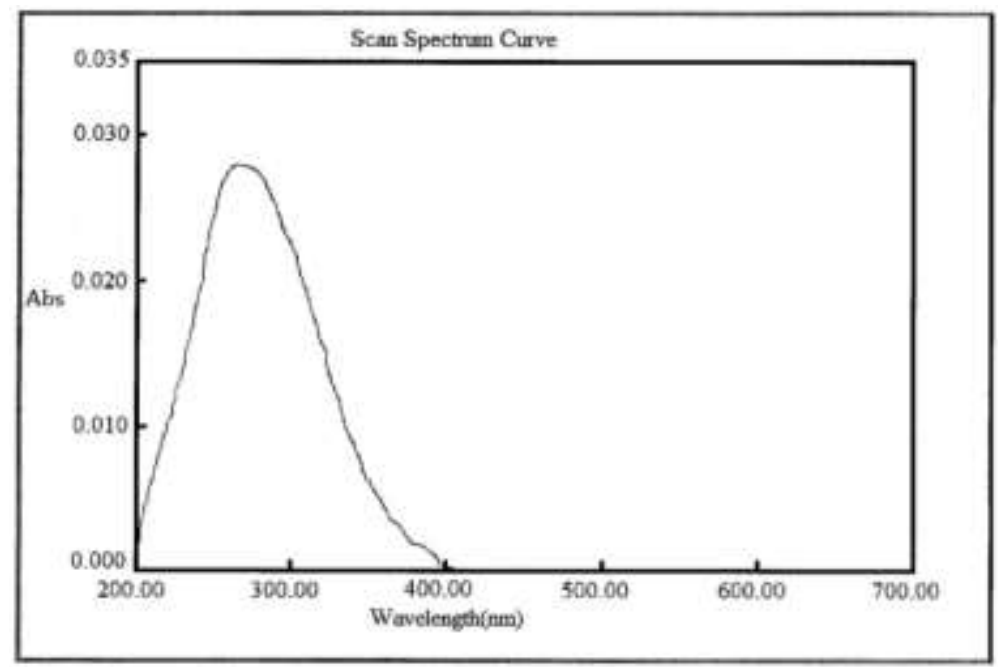

Figure-4, Progesterone absorption spectrum (ng/ml)

3.3 Calibration curve of dopamine 


\section{University of Thi-Qar Journal Vol.12 No.1 Mar 2017 \\ Web Site: https://jutq.utq.edu.iq/index.php/main \\ Email: journal@jutq.utq.edu.iq}

The absorbance of the following standard solutions $(0.5,1.0,1.5$, and $2.0 \mathrm{ng} / \mathrm{ml})$ measured at the obtained $\lambda_{\max }(250 \mathrm{~nm})$, ethanol used as a blank, standard calibration curve built up by excel Microsoft-2007 as shown in Figure -5.

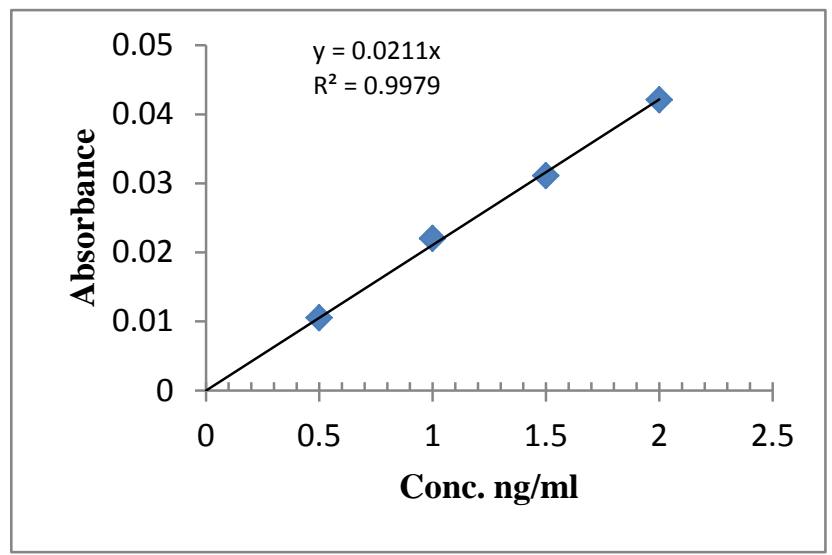

Figure-5, Dopamine standard calibration curve

\subsection{Calibration curve of progesterone}

The absorbance of the following standard solutions $(0.25,0.5,1.0$, and 1.5 $\mathrm{ng} / \mathrm{ml})$ measured at the obtained $\lambda_{\max }(266 \mathrm{~nm})$, chloroform used as a blank, standard calibration curve built up by excel Microsoft (2007) as shown in Figure -6.

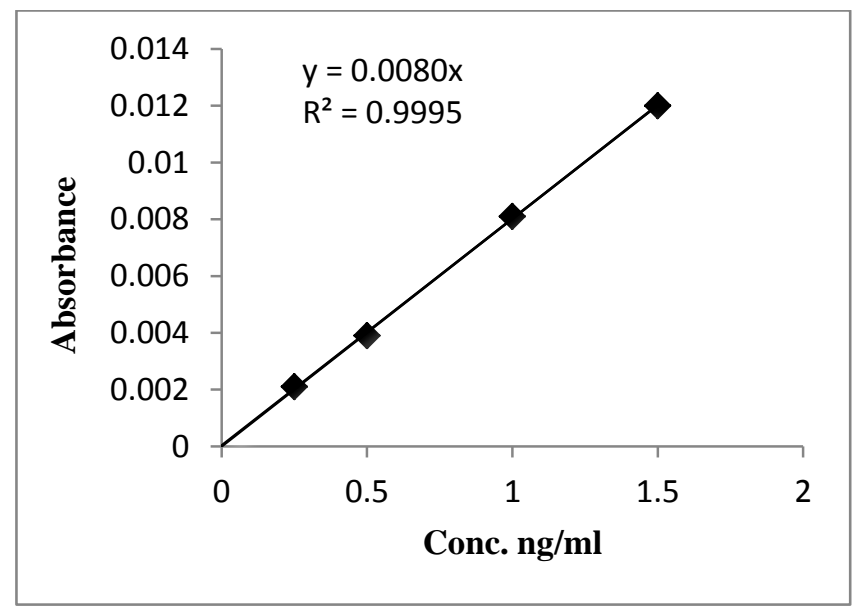




\section{University of Thi-Qar Journal Vol.12 No.1 Mar 2017 \\ Web Site: https://jutq.utq.edu.iq/index.php/main \\ Email: journal@jutq.utq.edu.iq}

Figure-6, Progesterone standard calibration curve

\subsection{Statistical Analysis}

The data was subjected to statistical analysis using the student t-test for comparison of hormones levels in patient and control groups. All the data were expressed as mean and standard deviation of the mean. The calibration graph follows the straight line equation $\mathrm{Y}=\mathrm{a} \times \mathrm{C}+\mathrm{b}$; where the $\mathrm{C}$ is the concentration of the analyte, $\mathrm{Y}$ is measured absorbance or peak height and $\mathrm{a} \& \mathrm{~b}$ are constants. By substituting the corresponding experimental data substituted in the above equation, the calibration equations were calculated for dopamine, progesterone as $\mathrm{A}_{266}=0.008 \times \mathrm{C}, \mathrm{A}_{250}=0.0211 \times \mathrm{C}$ respectively as shown in Figure-5, Figure-6.Further Beers law is obeyed in the ranges of $(0.5-2.0,0.25-$ $1.5 \mathrm{ng} / \mathrm{ml}$ ) for dopamine, progesterone respectively, the molar absorptivity, correlation coefficient $\left(\mathrm{R}^{2}\right)$, limit of detection (LOD) for dopamine, progesterone are $\left(\varepsilon=2.5156 \times 10^{6}, 4.1935 \times 10^{6} \mathrm{~L} \cdot \mathrm{mol}^{-1} \mathrm{~cm}^{-}\right.$ $\left.{ }^{1}\right), \quad(\mathrm{R}=0.9979,0.99957)$ and $(0.64,0.57 \mathrm{ng} / \mathrm{ml})$ respectively as showinTable1. The mean and the standard deviation of dopamine method for twenty eight determinations for control and patient groups are $(10.8673 \pm 3.6353 \mathrm{ng} / \mathrm{ml}),(6.8212 \pm 1.6871 \mathrm{ng} / \mathrm{ml})$ respectively as shown in Table-2. The mean and the standard deviation of progesterone method for the same twenty eight determination samples for control and patient groups are $(5.4598 \pm 2.6597 \mathrm{ng} / \mathrm{ml}),(7.0625 \pm 1.6049 \mathrm{ng} / \mathrm{ml})$ respectively as shown in table-3. The mean concentration of dopamine and progesterone in control and patient groups are $(10.8673,6.8212$ $\mathrm{ng} / \mathrm{ml}),(5.4598,7.0625 \mathrm{ng} / \mathrm{ml})$ respectively as shown in Figure-6.

Table-1 Optical characteristics and validation parameters of dopamine and progesterone

\begin{tabular}{|l|l|l|}
\hline Parameter & Dopamine & Progesterone \\
\hline
\end{tabular}


University of Thi-Qar Journal Vol.12 No.1 Mar 2017

Web Site: https://jutq.utq.edu.iq/index.php/main

Email: journal@jutq.utq.edu.iq

\begin{tabular}{|c|c|c|}
\hline$\lambda_{\max } \mathrm{nm}$ & 250 & 266 \\
\hline Beer's law limits, ng/mL & $0.5-2.0$ & $0.25-1.5$ \\
\hline $\begin{array}{r}\text { Molar absorptivity, } 1 / \mathrm{mol} . \\
\mathrm{cm}\end{array}$ & $4.1935 \times 10^{6}$ & $2.5156 \times 10^{6}$ \\
\hline Regression equation & $A=0.0211 \times C$ & $\begin{array}{r}\mathrm{A}= \\
0.008 \times \mathrm{C} \\
\end{array}$ \\
\hline $\begin{array}{l}\text { Correlation coefficient } \\
\left(\mathrm{R}^{2}\right)\end{array}$ & 0.9979 & 0.9995 \\
\hline LOD limit of detection & $0.64 \mathrm{ng} / \mathrm{ml}$ & $0.57 \mathrm{ng} / \mathrm{ml}$ \\
\hline Slop (b) & 0.0211 & 0.0080 \\
\hline
\end{tabular}


University of Thi-Qar Journal Vol.12 No.1 Mar 2017

Web Site: https://jutq.utq.edu.iq/index.php/main

Email: journal@jutq.utq.edu.iq

\begin{tabular}{|c|c|c|c|c|c|c|}
\hline Hormone & Group & $\mathrm{n}$ & $\begin{array}{c}\text { Mean } \pm \text { SD } \\
(\mathrm{ng} / \mathrm{ml})\end{array}$ & $\begin{array}{c}\text { Min. } \\
(\mathrm{ng} / \mathrm{ml})\end{array}$ & $\begin{array}{c}\text { Max. } \\
(\mathrm{ng} / \mathrm{ml})\end{array}$ & p-value \\
\hline \multirow{2}{*}{ Progesterone } & Control & 28 & $5.4598 \pm 2.6597$ & 3.750 & 9.750 & \multirow{2}{*}{$\mathrm{P}<0.05$} \\
\cline { 2 - 6 } & Patient & 28 & $7.0625 \pm 1.6049$ & 2.750 & 13.625 & \\
\hline \multirow{2}{*}{ Dopamine } & Control & 28 & $10.8673 \pm 3.6353$ & 5.238 & 17.857 & \multirow{2}{*}{$\mathrm{P}<0.05$} \\
\cline { 2 - 6 } & Patient & 28 & $6.8212 \pm 1.6871$ & 4.028 & 10.900 & \\
\hline
\end{tabular}

Table-2 Statistical analysis of progesterone and dopamine

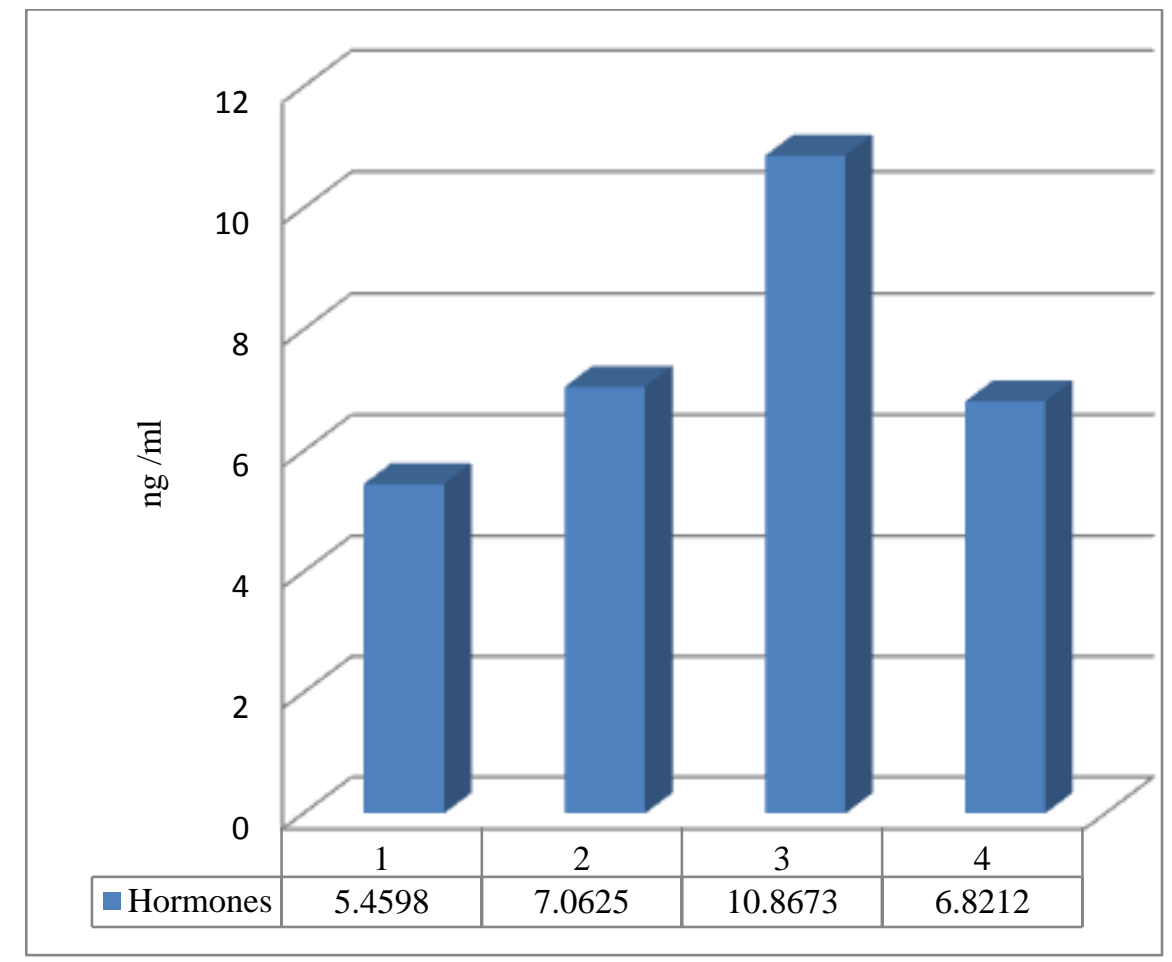

Figure-6 Mean concentrations of groups, 1. progesterone control,

2.progerterone patient, 3.dopamine control, 4. dopamine patient 


\section{University of Thi-Qar Journal Vol.12 No.1 Mar 2017 \\ Web Site: https://jutq.utq.edu.iq/index.php/main \\ Email: journal@jutq.utq.edu.iq}

\subsection{Conclusion}

The dopamine and progesterone concentrations were expressed as mean \pm standard deviation (SD) and range (minimum-maximum). The associations between serum levels of dopamine and progesterone in control and patient groups were determined by Pearson's correlation. $\mathrm{P}$ values less than 0.05 were considered statistically significant and all statistical tests were two-sided. Pearson's correlation analyses revealed significant correlations between the levels of dopamine and progesterone in control and patient groups as shown in table-2.

The results shows that the mean concentrations of dopamine in control group is higher than the patient group $(10.8673,6.8212 \mathrm{ng} / \mathrm{ml})$ as shows in Figure-6, maybe related to the psychology reasons, there is a significant difference between the patient and control groups at level $\mathrm{p}<0.05$.

Furthermore results shows that the mean of progesterone concentration in patient group is higher than the control group $(7.0625,5.4598 \mathrm{ng} / \mathrm{ml})$ as shown in Figure-6, so the increasing of the mean concentration of progesterone in patient group than the control group will activate the growth of the cancer cells in the breast. There is a significant difference between the patient and control groups at level $\mathrm{p}<0.05$.

In general the mean concentrations of dopamine were lower and progesterone higher in breast cancer patient group than the control group. That means these two hormones can be considered as a biomarkers in breast cancer diagnostic methods. This paper presents a spectrophotometric evaluation of dopamine and progesterone in serum which absorbs maximally at about 250,266 nm for dopamine and progesterone respectively. The proposed method is simple, precise and accurate for the determination of dopamine and progesterone in hospitals.

\section{Acknowledgement}

The author would like to thank Al-Sader public hospital in Misan for their cooperation to collect the samples. 
University of Thi-Qar Journal Vol.12 No.1 Mar 2017

Web Site: https://jutq.utq.edu.iq/index.php/main

Email: journal@jutq.utq.edu.iq 


\section{University of Thi-Qar Journal Vol.12 No.1 Mar 2017 \\ Web Site: https://jutq.utq.edu.iq/index.php/main \\ Email: journal@jutq.utq.edu.iq}

\section{References}

1. Elhag S, Ibupoto ZH, Liu XJ, Nur O, Willander M. "Dopamine wide range detection sensor based on modified $\mathrm{Co}_{3} \mathrm{O}_{4}$ nanowires electrode", Sens Actuator B: Chem. 2014;203:543-549.

2. Van Staden JF, van Staden RIS. "Flow-injection analysis systems with different detection devices and other related techniques for the in vitro and in vivo determination of dopamine as neurotransmitter". A review, Talanta 2012; 102 (S1):34-43.

3. Yang ZP, Liu X, Wu YM, Zhang CJ. "Modification of carbon aerogel electrode with molecularly imprinted polypyrrole for electrochemical determination of dopamine", Sens Actuator B: Chem 2015; 212:457-463.

4. Jackowska K, Krysinski P. "New trends in the electrochemical sensing of dopamine", Anal Bioanal Chem 2013; 405(11):3753- 3771.

5. Perry $\mathrm{M}, \mathrm{Li} \mathrm{Q}$, Kennedy RT. "Review of recent advances in analytical techniques for the determination of Neurotransmitters", Anal Chim Acta 2009; 653(1):1-22.

6. A. Biryuk, V. V. Petrenko, and B. P. Zorya, "Spectrophotometric determination of dopamine by reaction with ninhydrine", Farmatsevticheskii Zhurnal, vol. 2, p. 57, 1992.

7. K. R. Dutt, T. N. Prasad, M. S. Murthy and E. V. Rao, "Spectrophotometric determination of dopamine hydrochlo- ride using MBTH and CE(IV)", Indian Drugs, vol. 29, no. 4, pp.181-183, 1992.

8. C. Martinez-Lozano, T. Perez-Ruiz, V. Tomas, and O. Val, "Determination of epinephrine, norepinephrine, dopamine and Ldopa in pharmaceuticals by a photokinetic method", Analyst, vol. 116, no. 8, pp. 857-859, 1991.

9. M. E. el-Kommos, F. A. Mohamed, and A. S. Khedr, "Spectrophotometric determination of some catecholamine drugs using metaperiodate", Journal of the Association of Official Analytical Chemists, vol. 73, no. 4, pp. 516-520, 1990. 


\section{University of Thi-Qar Journal Vol.12 No.1 Mar 2017 \\ Web Site: https://jutq.utq.edu.iq/index.php/main \\ Email: journal@jutq.utq.edu.iq}

10. G. R. Rao, A. B. Avadhanulu, and R. Giridhar, "Spectrophoto- metric determination of dopamine hydrochloride, dobutamine hydrochloride in their dosage forms",Indian Drugs, vol. 25, no.9, pp. 382-384, 1988.

11. M. E. El-Kommos, "Spectrophotometric assay of dopamine hydrochloride injection using thiosemicarbazide", Journal de Pharmacie de Belgique, vol. 42, no. 6, pp. 371-376, 1987.

12. R. T. Sane, P. M. Deshpande, C. L. Sawant, S. M. Dolas, V. G. Nayak, and S. S. Zarapkar, "Simple spectrophotometric method for the determination of dopamine hydrochloride", Indian Drugs, vol. 24, p. 199, 1987.

13. C. S. Sastry, V. G. Das, and K. E. Rao, "Spectrophotometric methods for the determination of o-dihydroxybenzene deriva- tives", Analyst, vol. 110, no. 4, pp. 395-398, 1985.

14. F. Ortega and E. Domínguez, "Selective catalytic detection of dopamine", Journal of Pharmaceutical and Biomedical Analysis, vol. 14, no. 8-10, pp. 1157-1162, 1996.

15. J. J. B. Nevado, J. M. L. Gallego, and P. B. Laguna, "Flow- injection spectrophotometric determination of adrenaline and dopamine with sodium hydroxide", Journal of Pharmaceutical and Biomedical Analysis, vol. 14, no. 5, pp. 571-577, 1996.

16. J. J. Berzas Nevado, J. M. Lemus Gallego, and P. Buitrago Laguna, "Spectrophotometric determination of dopamine and methyldopa with metaperiodate by flow injection analysis", Fresenius' Journal of Analytical Chemistry, vol. 353, no. 2, pp.221-223, 1995.

17. J. J. Berzas, J. M. Lemus, and P. Buitrago, "Stopped-flow spectrophotometric determination of dopamine and methyldopa with sodium hydroxide", Analytical Letters, vol. 30, no. 6, pp.11091120,1997.

18. D. Djozan and M. A. Farajzadeh, "The use of fluorescamine (Fluram) in fluorimetric trace analysis of primary amines of pharmaceutical and biological interest", Journal of Pharmaceu- tical and Biomedical Analysis, vol. 10, no. 10-12, pp. 1063-1067,1992. 


\section{University of Thi-Qar Journal Vol.12 No.1 Mar 2017 \\ Web Site: https://jutq.utq.edu.iq/index.php/main \\ Email: journal@jutq.utq.edu.iq}

19. H. Y. Wang, Y. Sun, and B. Tang, "Study on fluorescence property of dopamine and determination of dopamine by fluorimetry", Talanta, vol. 57, no. 5, pp. 899-907, 2002.

20. H. Y. Wang, Q. S. Hui, L. X. Xu, J. G. Jiang, and Y. Sun, "Fluorimetric determination of dopamine in pharmaceutical products and urine using ethylene diamine as the fluorigenic reagent", Analytica Chimica Acta, vol. 497, no. 1-2, pp. 93-99,2003.

21. H. Nohta, T. Yukizawa, Y. Ohkura, M. Yoshimura, J. Ishida, and M. Yamaguchi, "Aromatic glycinonitriles and methylamines as precolumn fluorescence derivatization reagents for cate- cholamines", Analytica Chimica Acta, vol. 344, no. 3, pp. 233-240, 1997.

22. K. Fujino, T. Yoshitake, J. Kehr, H. Nohta, and M. Yamaguchi, "Simultaneous determination of 5-hydroxyindoles and cate- chols by high-performance liquid chromatography with fluo- rescence detection following derivatization with benzylamine and 1,2diphenylethylenediamine", Journal of Chromatography A, vol. 1012, no. 2, pp. 169-177, 2003.

23. X. Wu, C. Tong, B. Su, F. Huang, and J. Yang, "Determination of dopamine by fluorimetry", Fenxi Huaxue, vol. 27, no. 9, pp.1069-1071, 1999.

24. X. Zhu, P. N. Shaw and D. A. Barrett, "Catecholamines derivatized with 4-fluoro-7-nitro-2,1,3-benzoxadiazole: charac- terization of chemical structure and fluorescence properties", Analytica Chimica Acta, vol. 478, no. 2, pp. 259-269, 2003.

25. N. T. Deftereos, A. C. Calokerinos, and C. E. Efstathiou, "Flow injection chemiluminometric determination of epinephrine, norepinephrine, dopamine and L-dopa", Analyst, vol. 118, no. 6, pp. 627-632, 1993.

26. T. Peng, L. Yang, H. Yang, G. Wang, and B. Shen, "Selective accumulation and electrochemical behavior of neurotransmit- ter dopamine at glassy carbon electrode modified by sodium montmorillonite", Fenxi Huaxue, vol. 25, no. 1, pp. 5-9, 1997.

27. W. Peng and E. Wang, "Preparation and characterization of a multicylinder microelectrode coupled with a conventional glassy carbon 


\section{University of Thi-Qar Journal Vol.12 No.1 Mar 2017 \\ Web Site: https://jutq.utq.edu.iq/index.php/main \\ Email: journal@jutq.utq.edu.iq}

electrode and its application to the detection of dopamine", Analytica Chimica Acta, vol. 281, no. 3, pp. 663-671, 1993.

28. O. Niwa, M. Morita, and H. Tabei, "Highly sensitive and selective voltammetric detection of dopamine with vertically separated interdigitated array electrodes", Electroanalysis, vol. 3, no. 3, pp. 163168, 1991.

29. E. Bishop and W. Hussein, "Anodic voltammetry of dopamine, noradrenaline and related compounds at rotating disc elec- trodes of platinum and gold",Analyst, vol. 109, no. 5, pp. 627-632, 1984.

30. G. Fogg, A. M. Summan, and M. A. Fernandez-Arciniega, "Flow injection amperometric determination of ascorbic acid and dopamine at a sessile mercury drop electrode without deoxygenation", Analyst, vol. 110, no. 4, pp. 341-343, 1985.

31. J. L. Ponchon, R. Cespuglio, F. Gonon, M. Jouvet, and J. Francois Pujol, "Normal pulse polarography with carbon fiber electrodes for in vitro and in vivo determination of catecholamines", Analytical Chemistrty, vol. 51, no. 9, pp. 1483-1486, 1979.

32. Y. Wu, R. Fan, and J. Di, "Electrochemical study of electron transfer between dopamine and ferrocene at liquid/liquid inter- face", Fenxi Huaxue, vol. 24, no. 8, pp. 873-876, 1996.

33. S. Yixin and $\mathrm{S}$. Fu Wang, "Simultaneous determination of dopamine and ascorbic acid at a triazole self-assembled monolayermodified gold electrode", $\mathrm{M}$ icrochimica Acta, vol.154, no. 1-2, pp. 115-121, 2006.

34. I. Gopalan, K.-P. Lee, K. M. Manesh, P. Santhosh, J. H. Kim, and J. S. Kang, "Electrochemical determination of dopamine and ascorbic acid at a novel gold nanoparticles distributed poly(4aminothiophenol) modified electrode", Talanta, vol. 71, no. 4, pp. 1774-1781, 2007.

35. J. B. Raoof, A. Kiani, R. Ojani, R. Valiollahi, and S. RashidNadimi, "Simultaneous voltammetric determination of ascorbic acid and dopamine at the surface of electrodes modified with selfassembled gold nanoparticle films", Journal of Solid State Electrochemistry, vol. 14, no. 7, pp. 1171-1176, 2010. 


\section{University of Thi-Qar Journal Vol.12 No.1 Mar 2017 \\ Web Site: https://jutq.utq.edu.iq/index.php/main \\ Email: journal@jutq.utq.edu.iq}

36. D. Ragupathy, A. I. Gopalan, and K.-P. Lee, "Electrocatalytic oxidation and determination of ascorbic acid in the presence of dopamine at multiwalled carbon nanotube-silica network-gold nanoparticles based nanohybrid modified electrode", Sensors and Actuators B, vol. 143, no. 2, pp. 696-703, 2010.

37. X. Cao, L. Luo, Y. Ding, X. Zou, and R. Bian, "Electrochemical methods for simultaneous determination of dopamine and ascorbic acid using cetylpyridine bromide/chitosan composite filmmodified glassy carbon electrode", Sensors and Actuators B, vol. 129, no. 2, pp. 941-946, 2008.

38. L.-Q. Luo, Q.-X. Li, Y.-P. Ding, Y. Zhang, and X. Shen, "Docosyltrimethylammonium chloride modified glassy carbon electrode for simultaneous determination of dopamine and ascorbic acid", Journal of Solid State Electrochemistry, vol. 14, no.7, pp. 1311-1316, 2010.

39. M. Reza Hormozi Nezhad, J. Tashkhourian, J. Khodaveisi, and M. Reza Khoshi, "Simultaneous colorimetric determination of dopamine and ascorbic acid based on the surface plasmon resonance band of colloidal silver nanoparticles using artificial neural networks", Analytical Methods, vol. 2, no. 9, pp. 1263-1269, 2010.

40. De Benedetto GE, Fico D, Pennetta A, Malitesta C, Nicolardi G, Lofrumento DD et al. "A rapid and simple method for the determination of 3,4-dihydroxyphenylacetic acid, norepinephrine, dopamine, and serotonin in mouse brain homogenate by HPLC with fluorimetric detection", J Pharm Biomed Anal 2014, 98:266270.

41. Park JY, Myung SW, Kim IS, Choi DK, Kwon SJ, Yoon SH. "Simultaneous measurement of serotonin, dopamine and their metabolites in mouse brain extracts by high- performance liquid chromatography with mass spectrometry following derivatization with ethyl chloroformate", Biol Pharm Bull 2013; 36(2):252-258. 


\section{University of Thi-Qar Journal Vol.12 No.1 Mar 2017 \\ Web Site: https://jutq.utq.edu.iq/index.php/main \\ Email: journal@jutq.utq.edu.iq}

42. Coombs, M. M.; Bhatt, T. S.; Cyclopenta (a) phenanthrenes: "Polycyclic Aromatic Compounds Structurally Related to Steroids"; Cambridge University Press: Cambridge, 1987.

43. Arcand-Hoy, L. D.; Nimrod, A. C.; Benson, W. H.; "Endorinemodulation substances in the environment, estrogenic effects of pharmaceutical products "Int. J. Toxicol. 1998, 17, 139.

44. Ruggiero, R, "Estrogen: physiology pharmacology, and formulations for replacement therapy " J. Midwifery \& Women's Health 2002, 47, 130-138.

45. Polonini, H. C.; Soldati, P. P.; Oliveira, M. A. L.; Brandão, M. A. F.; Chaves, M. G. M.; Raposo, N. R. B.; "Transdermal formulations containing human sexual steroids: development validation of methods and in vitro drug release", Quim. Nova 2014,37, 720.

46. Bocian, S.; Soukup, J.; Matyska, M.;"The influence of the modifier in hydro-organic mobile phase on separation selectivity of steroid hormones separation using cholesterol- bonded stationary phase" J. Chromatogr. A 2012, 1245, 90.

47. Britz-McKibbin, P.; Ichihashi, T.; Tsubota, K.; Chen, D. D. Y.; Terabe, S.;" Complementary on-line preconcentration strategies for steroids by capillary electrophoresis" J. Chromatogr. A 2003, 1013, 65.

48. Flor, S.; Lucangioli, S.; Contin, M.; Tripodi, V.; "Simultaneous determination of nine endogenous steroid in human urine by polymetric- mixed micelle capillary electrophoresis" Electrophoresis 2010, 31, 3305.

49. Jin, W.; Fu, H.; Huang, X.; Xiao, H.; Zou, H.; "Optimized preparation of poly(styrene-co-divinylbenzene-co-methacrylic acid) monolithic capillary column for capillary electrochromatography" Electrophoresis 2003, 24, 3172-3180.

50. Wang, X.; Ding, K.; Yang, C.; Lin, X.; Lü, H.; Wu, X.; Xie, Z.; Electrophoresis 2010, 31, 2997.

51. Smith, N. W.; Carter-Finch,A. S.; "Review electrochromatography"J. Chromatogr. A 2000, 892, 219. 


\section{University of Thi-Qar Journal Vol.12 No.1 Mar 2017 \\ Web Site: https://jutq.utq.edu.iq/index.php/main \\ Email: journal@jutq.utq.edu.iq}

52. Graham JD, Clarke CL. "Physiological action of progesterone in target tissues". Endocr Rev. 1997; 18: 502-519. [PubMed: 9267762].

53. Mendelson CR. Minireview: "fetal-maternal hormonal signaling in pregnancy and labor". Mol Endocrinol. 2009; 23:947-954. [PubMed: 19282364]. 